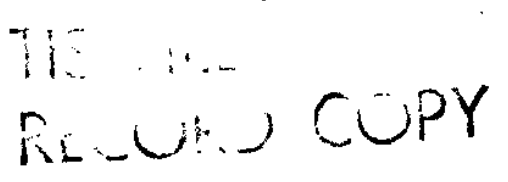

CALCULATION OF PARTICULATE DISPERSION IN A DESIGN-BASIS TORNADIC STORM FROM THE BABCOCK AND WILCOX PLANT, LEECHBURG, PENNSYLVANIA

D. W. Pepper 
This report was prepared as an account of work sponsored by the United States Government. Neither the United States nor the United States Department of Energy, nor any of their contractors, subcontractors, or their employees, makes any warranty, express or implied or assumes any legal liability or responsibility for the accuracy, completeness or usefulness of any information, apparatus. product or process disclosed, or represents that its use would not infringe privately owned rights.

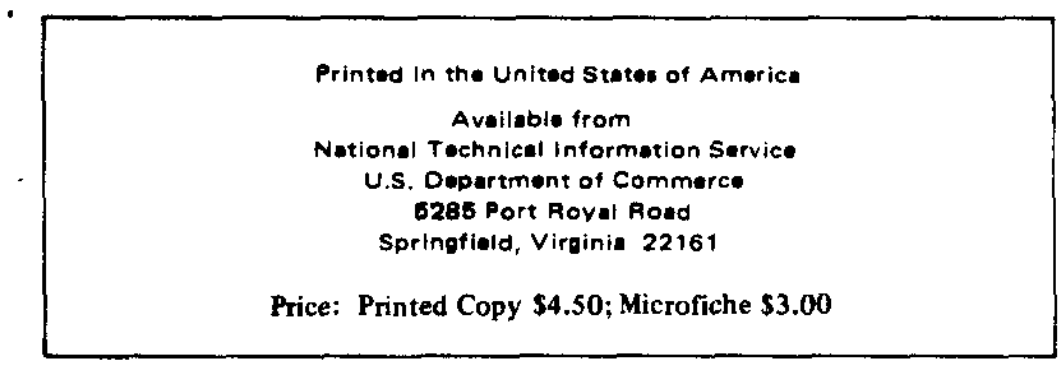




\section{CALCULATION OF PARTICULATE DISPERSION IN A DESIGN-BASIS TORNADIC STORM FROM THE BABCOCK AND WILCOX PLANT, LEECHBURG, PENNSYLVANIA}

by

D. W. Pepper

Approved by

T. V. Crawford, Research Manager

Environmental Transport Division

Publication Date: March 1978

E. I. DU PONT DE NEMOURS AND COMPANY SAVANNAH RIVER LABORATORY AIKEN, SOUTH CAROLINA 29801 


\section{ABSTRACT}

A three-dimensional numerical model is used to calculate ground-level air concentration and deposition (due to precipitation scavenging) after a hypothetical tornado strike at the Babcock and Wilcox Plutonium Fabrication Facility at Leechburg, Pennsylvania. Plutonium particles less than $20 \mu \mathrm{m}$ in diameter are assumed to be 1 ifted into the tornadic storm cell by the vortex. The rotational characteristics of the tornadic storm are embedded within the larger mesoscale flow of the storm system. The design-basis translational wind values are based on probabilities associated with existing records of tornado strikes in the vicinity of the plant site. Turbulence exchange coefficients are based on empirical values deduced from experimental data in severe storms and from theoretical assumptions obtained from the literature. The quasi-Lagrangian method of moments is used to model the transport of concentration within a grid cell volume.

In all case studies, the effects of updrafts and downdrafts, coupled with scavenging of the particulates by precipitation, account for most of the material being deposited within $20-45 \mathrm{~km}$ downwind of the plant site. Ground-level isopleths in the $x-y$ plane show that most of the material is deposited behind and slightly to the left of the centerline trajectory of the storm. Approximately $5 \%$ of the material is dispersed into the stratosphere and anvil section of the storm. 


\title{
CONTENTS
}

\author{
Introduction 5 \\ Site Characteristics and Design-Basis Tornadoes 6 \\ Dispersion Mode1 7 \\ Results 10 \\ Conclusions 22 \\ References $\quad 24$
}




\section{LIST OF TABLES}

1 Windspeed Values and Probabilities of Occurrence 6

2 Average Sector Air Concentration at Ground Level 20

3 Average Sector Deposition at Ground Leve1 21

\section{LIST OF FIGURES}

1 Air Concentration in the $x-z$ Plane (center of plane passing through axis of tornado) 11

2 Ground Level Air Concentration in the $x-y$ Plane $(t=40 \mathrm{~min})$ (rotational winds represent tornadic storm) 11

3 Maximum Ground Level Centerline Air Concentration from Initialization Point in Storm 13

4 Maximum Ground Level Centerline Air Concentration from Plant Site 14

5 Ground Level Air Concentration Isolog Plots $\left(\mathrm{m}^{-3}\right)$ in the $x-y$ Plane $(t=60 \mathrm{~min}) \quad 15$

6 Ground Level Deposition Isolog Plots $\left(\mathrm{m}^{-2}\right)$ in the $x-y$ Plane $(t=60 \mathrm{~min}) \quad 16$

7 Maximum Ground Level Centerline Air Concentration $\left(\mathrm{m}^{-3}\right)$ - Modified Gaussian Model 18

8 Concentric Annuli in $22.5^{\circ}$ Sectors in the $x-y$ Plane 19 


\section{CALCULATION OF PARTICULATE DISPERSION IN A DESIGN-BASIS TORNADIC STORM FROM THE BABCOCK AND WILCOX PLANT, LEECHBURG, PENNSYLVANIA}

\section{INTRODUCTION}

This study is part of a series sponsored by the U.S. Nuclear Regulatory Commission and managed by Argonne National Laboratory regarding the radiological consequences of a hypothetical tornado striking a plutoniun fabrication facility. The report deals specifically with the meteorological dispersion of plutonium particles in a tornadic storm after the Babcock and Wilcox Plutonium Fabrication Plant at Leechburg, Pennsylvania is breached.

The risk assessment and site characterization of the Babcock and Wilcox Plant have been made by Fujita ${ }^{1}$ and were based on existing records of extreme windstorms and tornadoes. The storm characteristics were computed as a function of yearly probabilities in an effort to determine design-basis storms representative of the site. The design-basis wind values used in this study were based on threshold windspeeds corresponding to annual probabilities of $10^{-7}, 10^{-6}$, and $7.2 \times 10^{-6}$ occurrence.

The structural responses of the buildings and their components have been expressed in terms of threshold values of windspeed by Mehta et al. ${ }^{2}$ Damage postulations have been translated into consequences of damage to specific equipment and areas of the plant. These consequences are used as input information by Mishima et al. ${ }^{3}$ for estimating the amount and form of plutonium released into the atmosphere. 


\section{SITE CHARACTERISTICS AND DESIGN-BASIS TORNADOES}

Site topography and characteristics with windspeed values and probability of occurrence of a design-basis tornado are given in detail for the Babcock and Wilcox Plant by Fujita. ${ }^{1}$ In this study, windspeeds associated with $10^{-7}, 10^{-6}$, and $7.2 \times 10^{-6}$ probabilities per year for a tornadic storm striking the Babcock and Wilcox Plant are given in Table 1 .

\section{TABLE}

Windspeed Values $(\mathrm{m} / \mathrm{sec})$ and Probabilities of Occurrence

$\begin{array}{lrrr}\text { Probability per year } & 10^{-7} & 10^{-6} & 7.2 \times 10^{-6} \\ \text { Maximum total } & 125 & 96.5 & 67.0 \\ \text { Translational } & 25 & 19.2 & 13.4 \\ \text { Tangential } & 100 & 77.3 & 53.6\end{array}$

The radius of the tornado is assumed to be $150 \mathrm{~m}$ with the vortex extending to altitudes of $1000 \mathrm{~m}^{4}$ Fujita $^{1}$ reports that numerous tornadoes with windspeeds corresponding to these probabilities have occurred in the vicinity of the plant site. Mehta et al. ${ }^{2}$ and Mishima et $a l^{3}{ }^{3}$ estimated that each design-basis tornado causes enough damage to the Babcock and Wilcox Plant to allow unencapsulated plutonium particles to be lifted into the vortex.

Fujital shows that most small- and medium-sized tornadoes move in an east-northeast direction near the site, and largesized-tornadoes-(F4-F5) move-in-an-east-southeast direction. However, tornado strikes in the vicinity of the site are only based on a few years of data. As more precise information on windspeeds and directions of tornado-bearing storms become available, more realistic estimates of downwind dispersion patterns can be obtained. 


\section{DISPERSION MODEL}

The model is based on the solution of the three-dimensional time-dependent equation for pollutant transport:

$$
\frac{\partial C}{\partial t}+\vec{U} \cdot \nabla C=\nabla \cdot(\hat{K} \nabla C)+S
$$

where $\mathrm{C}$ is the concentration, $\mathrm{g} / \mathrm{m}^{3}$; $\overrightarrow{\mathrm{U}}$ is the vector velocity field, $\mathrm{m} / \mathrm{sec} ; \hat{\mathrm{K}}$ is the directionally dependent eddy diffusivity (exchange coefficient of diffusion, $\mathrm{m}^{2} / \mathrm{sec}$ ); and $\mathrm{S}$ represents the sink term associated with precipitation scavenging, $\mathrm{g} / \mathrm{m}^{3}-\mathrm{sec}$. The complexity of the flow fields associated with tornadic storms and the numerous scales of turbulence involved (which characterize the diffusion processes) do not permit simple solutions to Equation 1 .

Gaussian solutions have been used in the past for solution of Equation 1 under ideal steady state conditions. ${ }^{2}$ These solutions are not flexible enough to include the variations in updraft and downdraft velocities, as well as the regionally dependent scavenging within the thunderstorm cell. Vertical wind shear and scavenging contribute significantly to early deposition of radioactive particles. In order to accommodate the temporal and spatial variations of numerous meteorological parameters, including the effects of wind shear and wet deposition, a numerical method is used to solve Equation 1.

The problems of numerical dispersion errors and mesh refinement associated with numerical methods are reduced by using a quasi-Lagrangian scheme with an Eulerian finite difference method. To reduce the computer memory requirements needed to solve the three-dimensional equation of concentration transport, Equation 1 is split into a series of one-dimensional advection-diffusion equations. 6 The method involves splitting each individual onedimensional equation into a Lagrangian advection part plus an Eulerian diffusion part. The method of second moments is used to maintain subgrid scale resolution of the concentration.

The method of second moments is a unique quasi-Lagrangian scheme initially developed by Egan and Mahoney to model the transport of urban pollutants. The method calculates the zeroth, first, and second moments of the concentration within a mesh and then advects and diffuses the concentration by maintaining conservation of the moments. The moments correspond to the mean concentration, center of mass, and scaled distribution variance (moment of inertia), respectively. The method of moments was chosen in lieu of other numerical methods because of its ability to resolve steep gradients, to eliminate numerical dispersion 
errors, to maintain peak concentration values, and to minimize computation time. A more thorough analysis of the technique is discussed in References 8 and 9.

The initial conditions are crucial to the downwind dispersal patterns after the facility is breached. Radioactive debris is assumed to be picked up by the tornado and lifted into the thunderstorm cell. The puff consists of particles that vary in size from 1 to $20 \mathrm{\mu m}$. Once the pollutant reaches the thunderstorm cell (at a point where the vertical velocity within the tornado is less than the updraft velocity of the thunderstorm cel1), the puff is assumed to be dispersed according to the dynamics of the thunderstorm cell. I0 The puff is estimated to be completely distributed throughout the thunderstorm cell within $20 \mathrm{~min}$. The concentration within the thunderstorm cell is initialized by using a skewed log-normal distribution with maximum values centered on the axis of the tornado, according to the mass balance assumptions suggested by Fujita. Il Once the pollutant is disbursed within the storm, advection and turbulent diffusion, along with scavenging, act on the pollutant cloud.

Accurate mesoscale wind-field analyses are essential to correctly calculate the trajectory of the storm. However, the amount of information regarding thunderstorm cell dynamics is limited; therefore a complex three-dimensional solution of the equations of motion is not applicable at the present time. Instead, the wind vector, $U$, is obtained at each time step of integration by using empirical and experimental values suggested by Fujitall and Eagleman and Lin. ${ }^{12}$ The three-dimensional winds associated with the tornadic storm are discussed in greater detail in Reference 8.

The updraft and downdraft velocities vary with height within the thunderstorm cel1, ${ }^{11}$ decreasing to zero at the top of the anvil. The magnitude of the vertical wind speeds is chosen to be compatible with observations and measurements of vertical velocities within severe storms. Advection and diffusion of the horizontal distribution of the vertical velocity field (at the $1000-\mathrm{m}$ level of the cloud) enable the updraft and downdraft regions of the storm to be propagated with the trajectory of the storm.* Since rain occurs in nearly all tornadic storms, scavenging of the pollutant by raindrops is assumed to occur. Precipitation scavenging field experiments ${ }^{12,13}$ have shown that scavenging by storms greater than $10,000 \mathrm{ft}$ deep deposit a significant fraction of released tracer material.

* The rotational characteristics of the horizontal wind field within the storm cell are likewise propagated with the trajectory of the storm (procedures analogous to the vertical velocity field calculation). 
The sink term in Equation 1 is based on the removal rate of concentration due to raindrops falling through the thunderstorm ce11. The removal rate is calculated from empirical estimates and theoretical assumptions derived by Slinn. ${ }^{13}$ A water dropletparticulate collision efficiency of $100 \%$ is used. An average rainfall rate of $20 \mathrm{~mm} / \mathrm{hr}$ is assumed to occur throughout the lifetime of the storm. Although rainfall rates near the center of a severe storm can vary above $100 \mathrm{~mm} / \mathrm{hr}$, such high rainfall rates are not constant and fluctuate in location. The value of $20 \mathrm{~mm} / \mathrm{hr}$ is used as an ensemble average characteristic of severe storms. ${ }^{1}$ Since updrafts markedly reduce the deposition due to rainout, the removal rate is set equal to zero in those regions of the storm where vertical velocities are positive. This allows the rainfall to occur in those regions of the storm corresponding to the rainshaft and downdraft regions observed in actual storms. A more conservative approach would assume the effect of scavenging to occur over the entire horizontal extent of the thunderstorm. However, the recent study of the Lamont tornado by Fujita et al. ${ }^{14}$ indicates that in regions of moderate-to-intense updrafts, rainfall is nonexistent. 


\section{RESULTS}

Numerous cases were simulated to determine the most likely dispersion patterns as well as potential radiological hazard to the people. The results shown in this study should be regarded as conservative estimates.

Output of the numerical model consists of concentration values specified within individual cell volumes. These values are appropriately adjusted within cell volume to correspond to the spatial dimensions of the cell. Since the amount of radioactive debris picked up by a tornado varies according to the structural damage sustained, a unit release of material has been used to specify the source term. Results are presented as isopleths of ground-level air concentration (ratio of concentration to source mass, $\left.X / Q, \mathrm{~m}^{-3}\right)$ and surface deposition $\left(\mathrm{m}^{-2}\right)$ at $t=60$ minutes. Centerline ground-level values of air concentration (maximum values) are shown as a function of longitudinal distance along the trajectory of the storm. The isopleths are drawn with respect to distance from the point where the material is initially dispersed within the storm.

The convergence and divergence of the mesoscale wind field are not considered; therefore, the longitudinal wind transports the storm cell in a straight line. Since the direction of the tornadic storm is arbitrary, direction is independent of points of the compass. The influence of topography on advection is not considered.* Since dispersion is a function of translational windspeed, the translational velocities are input into the model corresponding to each design-basis tornado. Lateral dispersion along the trajectory of the storm is due primarily to the horizontal extent of the downdraft region (and rotational wind field) in the rear of the storm with minor influence from horizontal diffusion. Scavenging acts to dilute the concentration in the cloud such that ground-1evel air concentrations are less than ground-level values obtained without scavenging. A more detailed analysis of the effects of scavenging in the calculational procedure is discussed in Reference 8 .

The initial air concentration distribution $(X / Q)$ is shown in Figure $1 \mathrm{a}$ in the $\mathrm{x}-\mathrm{z}$ plane with the center of the plane passing through the axis of the tornado $(t=0)$. Figures $1 \mathrm{~b}$ and $1 \mathrm{c}$ show air concentration $\left(\mathrm{m}^{-3}\right)$ isopleths for $U=13.4 \mathrm{~m} / \mathrm{sec}$ in the $x-z$ plane at $t=5$ and $40 \mathrm{~min}$, respectively. Figure 2 shows ground-level air concentration in the $x-y$ plane at $t=40 \mathrm{~min}$.

* Further research into this problem would require the incorporation of a more realistic wind field ${ }^{12}$ as well as topography. 

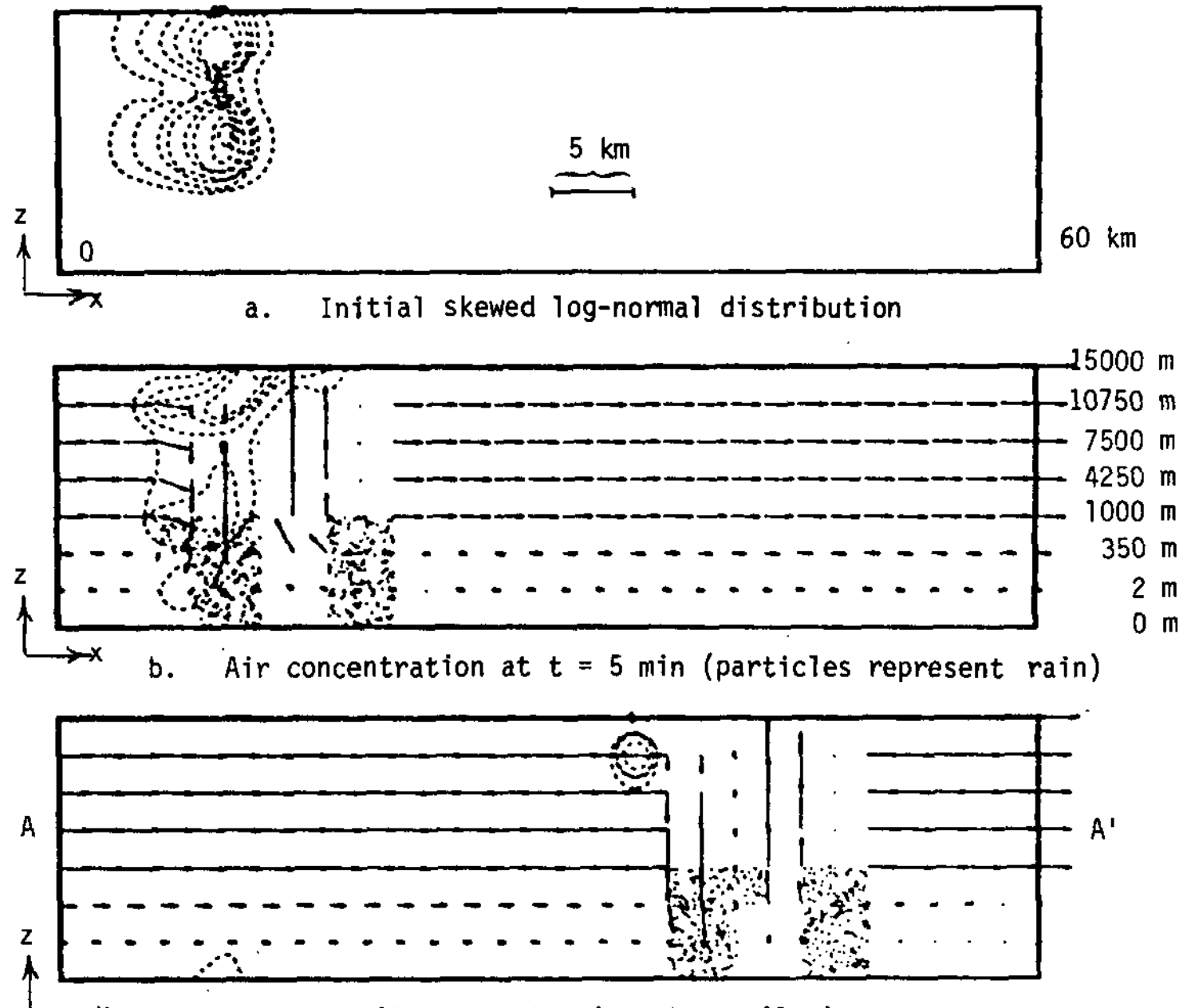

c. Air concentration at $t=40 \mathrm{~min}$

FIGURE 1. - Air Concentration in the $x-z$ Plane (center of plane passing through axis of tornado)

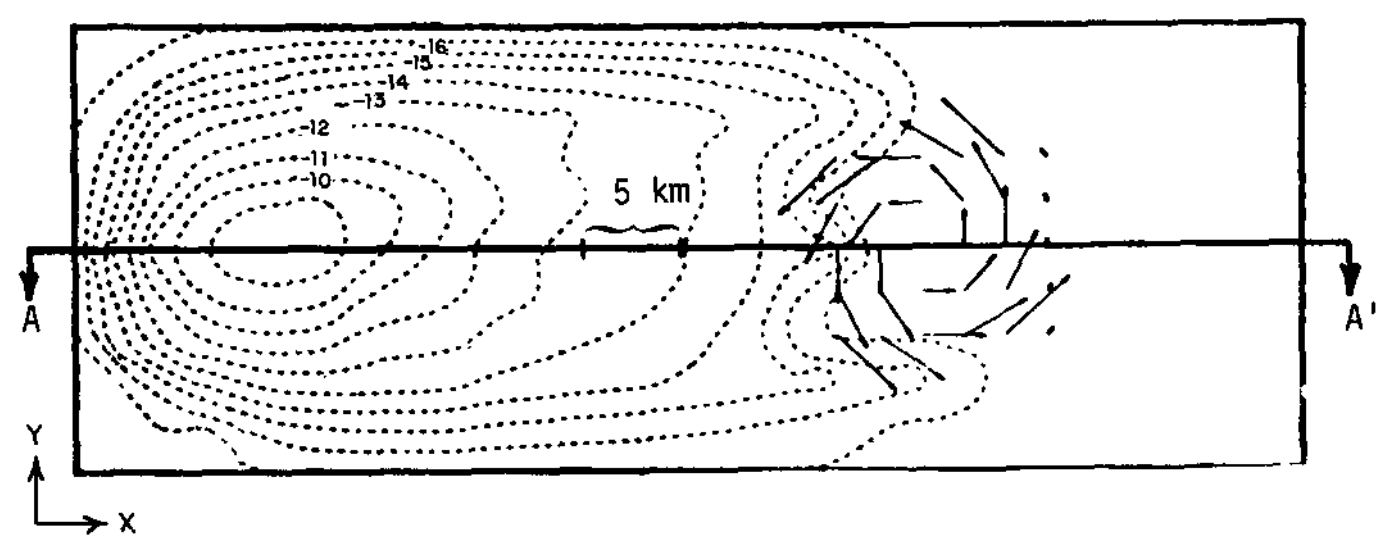

FIGURE 2. Ground Level Air Concentration in the $x-y$ Plane $(t=40 \mathrm{~min}$ ) (rotational winds represent tornadic storm) 
Ground-1evel centerline $X / Q$ values are shown in Figures 3 and 4 for each specific translational velocity. The displacement of concentration as a function of translational velocity is evident. In all three cases, $90 \%$ of the peak air concentration has reached ground level within one hour after initial dispersion within the cloud (20 min after uptake of the pollutant). The decrease of $X / Q$ values beginning at $X=20 \mathrm{~km}$ in Figure 3 is due to the depletion of concentration from the cloud (excepting that part transported to the anvil region) and to nearly complete diffusion of the concentration below cloud base to the ground.

Isopleths of air concentration at ground level for $t=60 \mathrm{~min}$ are shown in Figure 5 corresponding to storm translational velocities of $U=13.4,19.2$, and $25.0 \mathrm{~m} / \mathrm{sec}$, respectively. The irregularity in the isopleth contours is due primarily to the advection and diffusion of the updraft/downdraft regions on the storm with time. The ground-level layer consists of unit cells with dimensions of $2000 \mathrm{~m} \times 2000 \mathrm{~m} \times 2 \mathrm{~m}$. Figure 5 shows that as the translational velocity of the storm increases, the lateral spread of air concentration is stretched downwind. Higher peak concentration values appear less displaced to the right for the tornadic storm with a translational velocity of $13.4 \mathrm{~m} / \mathrm{sec}$ than with the succeeding two velocities. However, once beyond the initial peak concentration area, downwind values of ground-level air concentration are less than values obtained for $U=19.2$ and $25.0 \mathrm{~m} / \mathrm{sec}$. This is to be expected because the increase in advection causes the peak concentration values to be more dis placed (and distributed) in the longitudinal direction. Likewise, the slower the translational velocity, the more time turbulent diffusion, vertical advection, and rainout have to act on the airborne concentration.

In test cases run without the influence of updrafts and downdrafts (and scavenging), the air concentration eventually reached ground after 6 hours but was several orders of magnitude less in value. If the storm moves at $25 \mathrm{~m} / \mathrm{sec}$ for 6 hours, deposition at the surface would begin approximately $540 \mathrm{~km}$ from the Babcock and Wilcox Plant. However, studies made by Davis ${ }^{15}$ and Hane $^{16}$ indicate that it would be very unlikely for the pollutant to remain entirely within a storm cell for several hours without vertical wind shear and scavenging bringing a fraction of the pollutant to the surface.

Ground-1eve1 raindrop depositions $\left(\mathrm{m}^{-2}\right)$ are shown in Figure 6 for $U=13.4,19.2$, and $25.0 \mathrm{~m} / \mathrm{sec}$, respectively. The deposition patterns consist of raindrops that have scavenged pollutant from the storm cell and stick to the surface. As shown in Figures 3, 4, and 5, the effect of advection on air concentration is also evident on ground-level deposition: the highest peak values are obtained when $U=13.4 \mathrm{~m} / \mathrm{sec}$ with the peak region 


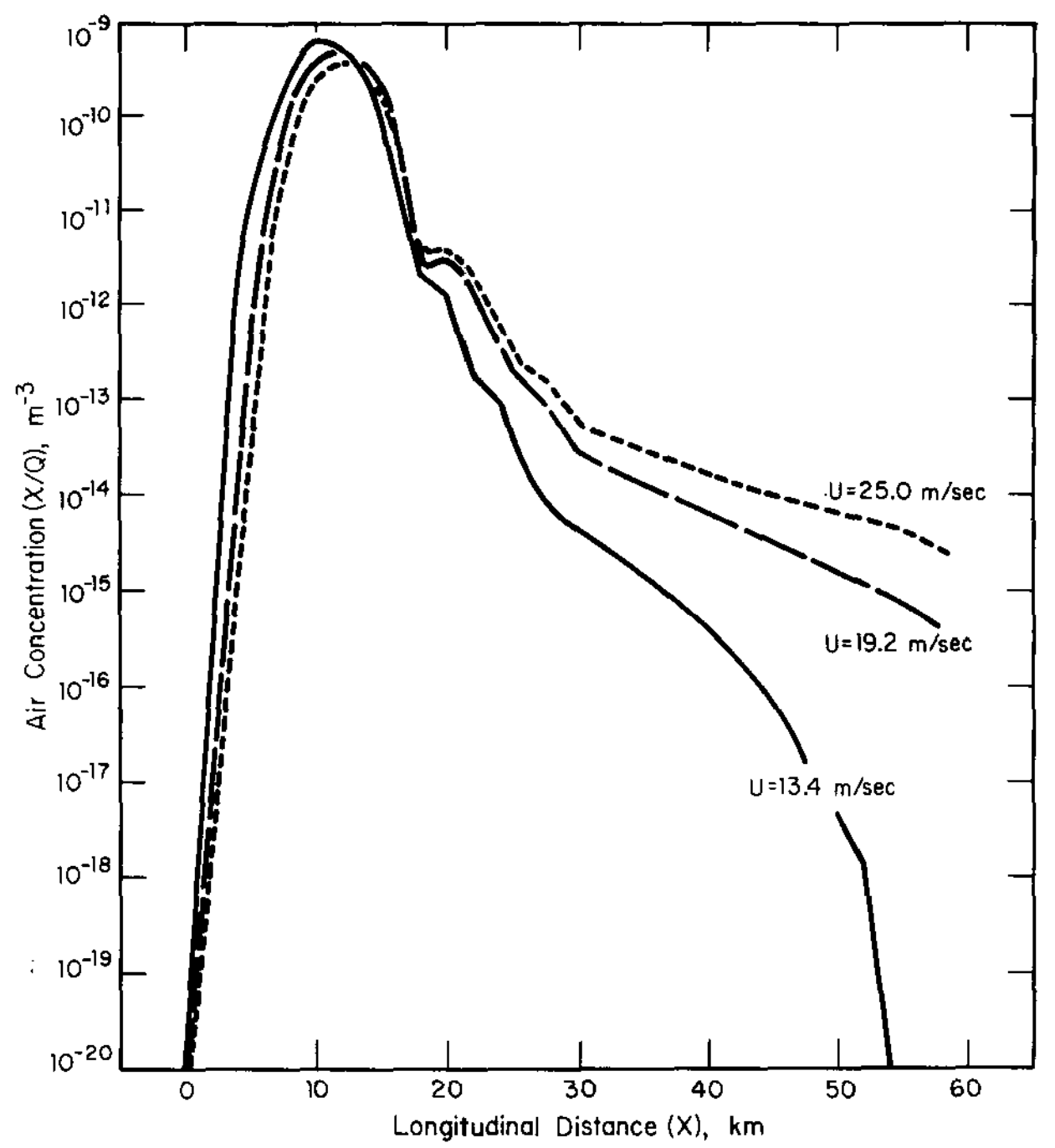

FIGURE 3. Maximum Ground Level Centerline Air Concentration from Initialization Point in Storm 


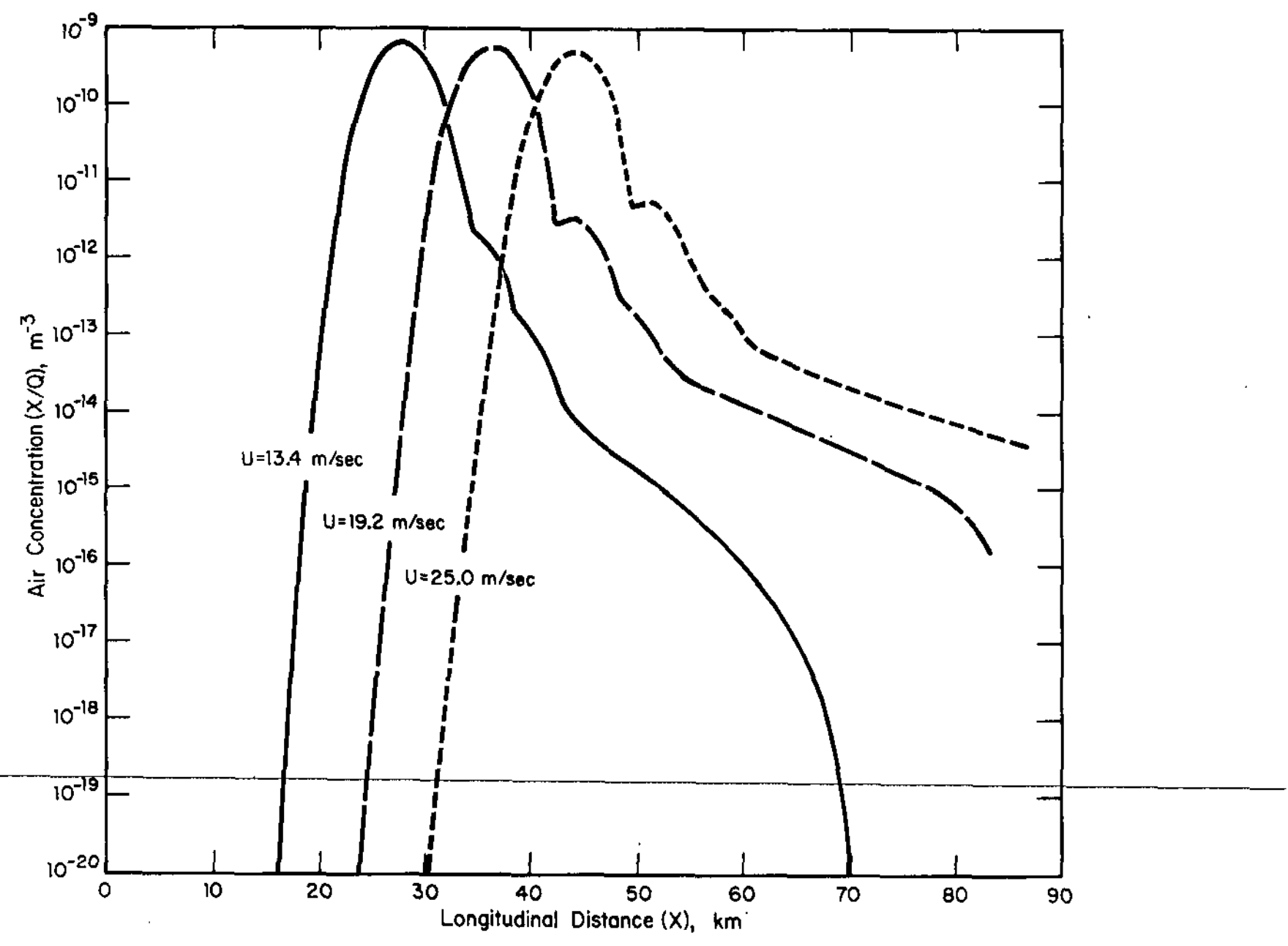

FIGURE 4. Maximum Ground Level Centerline Air Concentration from Plant Site 

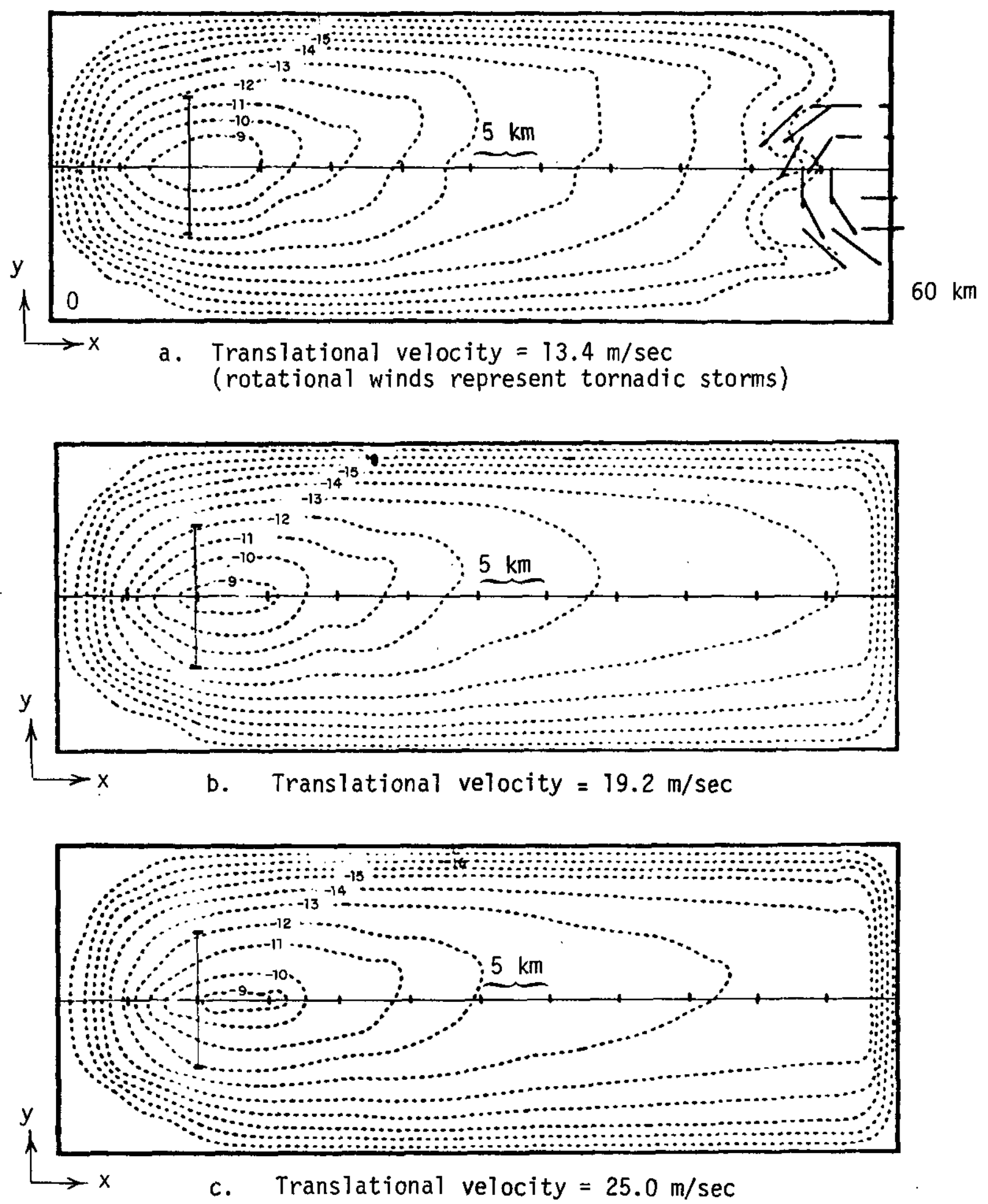

FIGURE 5. Ground Level Air Concentration Isolog Plots $\left(\mathrm{m}^{-3}\right)$ in the $x-y$ Plane $(t=60$ min $)$ 


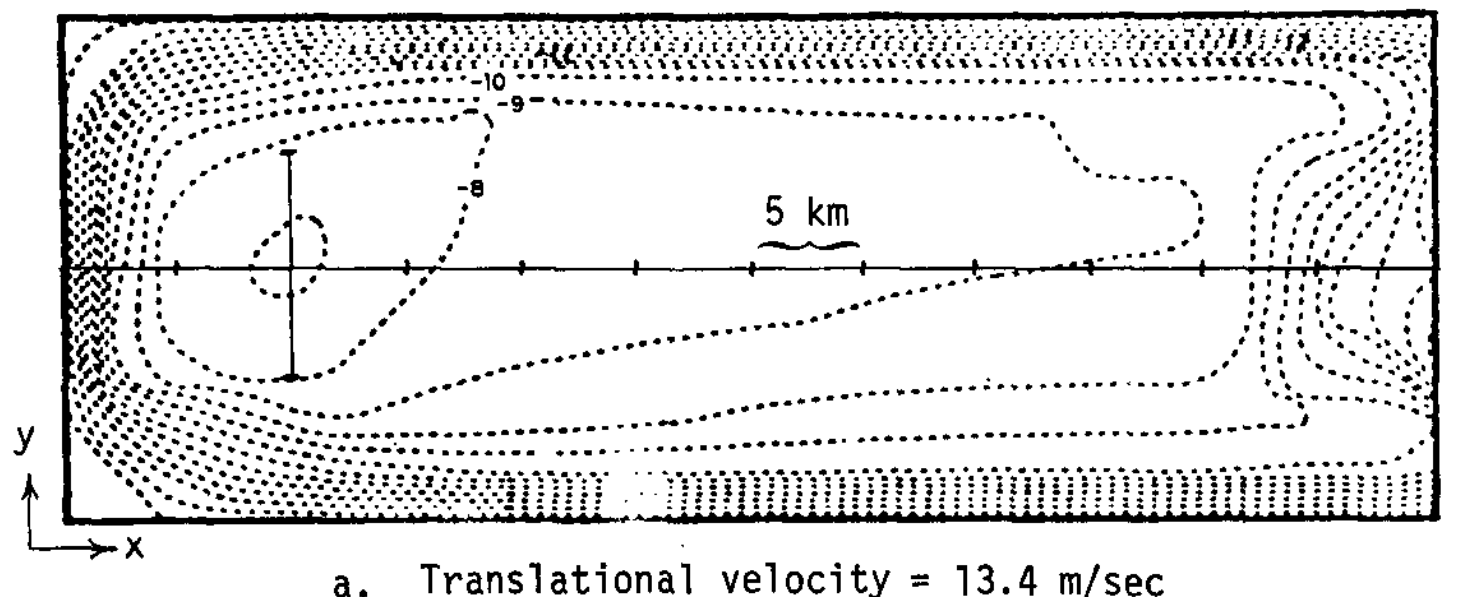

a. Translational velocity $=13.4 \mathrm{~m} / \mathrm{sec}$
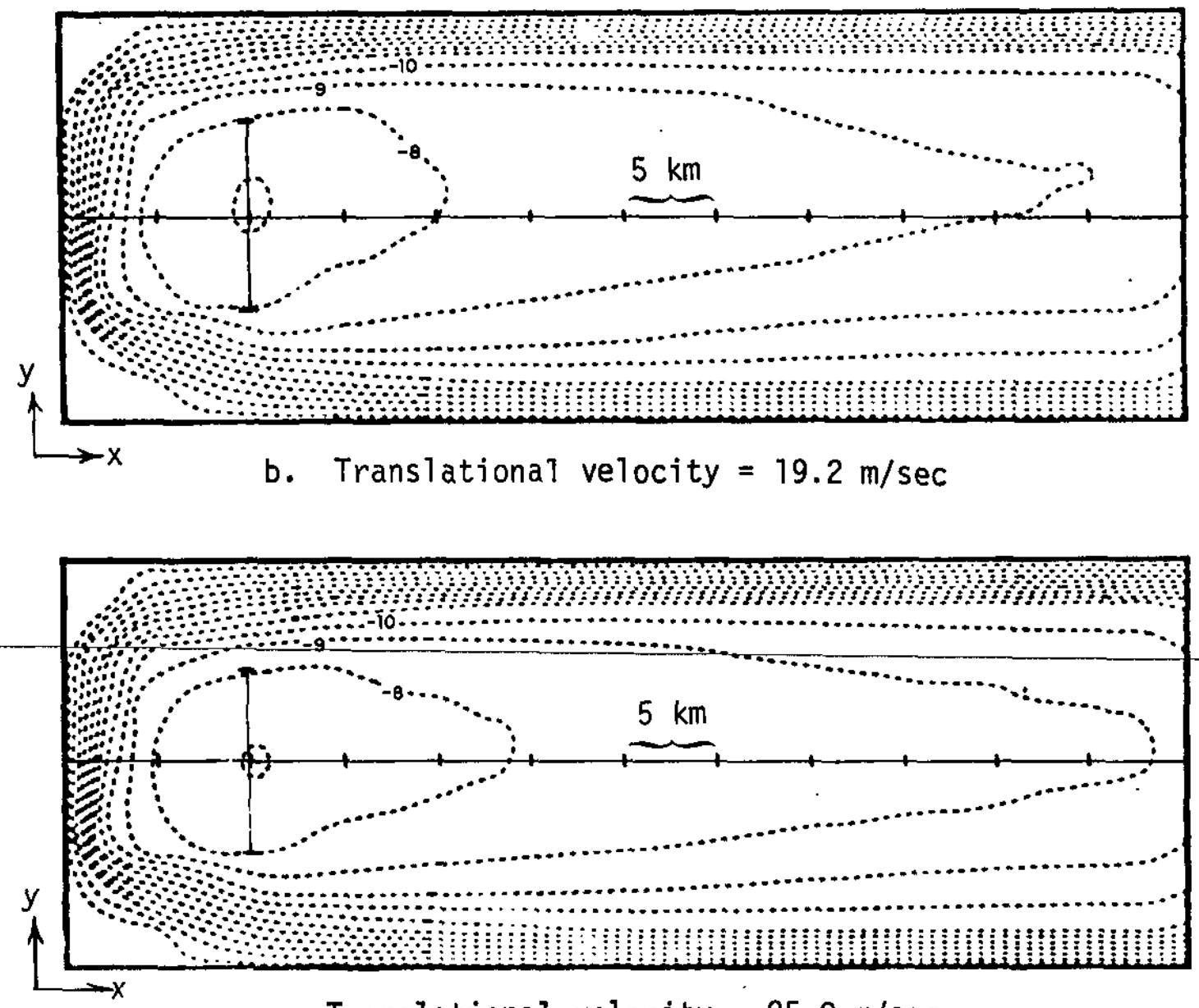

c. Translational velocity $=25.0 \mathrm{~m} / \mathrm{sec}$

FIGURE 6. Ground Level Deposition Isolog Plots $\left(\mathrm{m}^{-2}\right)$ in the $x-y$ Plane $(t=60 \mathrm{~min})$ 
being nearest to the initial dispersion point in the cloud; subsequent downwind values are less in value than the succeeding cases with $U=19.2$ and $25.0 \mathrm{~m} / \mathrm{sec}$. The increase in translational velocity causes the region of peak concentration to be shifted along the direction of the storm.

Based on the test cases analyzed in this study, early deposition of concentration occurs within 10 to 20 min after the initial dispersion of concentration within the storm cell. The primary mechanisms for concentration reaching the surface comes from the effect of the downdraft vertical velocity distribution and wet deposition. In all cases, $50 \%$ of the initial concentration, excepting that portion lifted into the anvil region of the cloud, is removed from the cloud within 15 minutes from the time of initial dispersion within the storm. The maximum groundlevel concentration in all cases occurs within 35 minutes of ground-level injection.

Maximum centerline air concentration values reveal that peak concentration at the surface occurs within $15 \mathrm{~km}$ from the point where the initial dispersion within the storm is established (Figure 3). The concentration is essentially depleted from the lower and middle layers of the cloud within $50 \mathrm{~km}$ of the peak ground-level value.

A modified Gaussian puff tornado model ${ }^{5}$ was also used to calculate ground-1evel air concentration. Figure 7 shows the Gaussian puff centerline values for $U=13.4,19.2$, and $25.0 \mathrm{~m} / \mathrm{sec}$. $X / Q$ values are several orders of magnitude lower than values obtained by the numerical method. This is principally due to the initial conditions assumed within the cloud (Gaussian in this case about cloud center) and lack of downdrafts. The curves in Figure 7 show the influence of advection on the downwind centerline concentration values. As velocity increases, the effect of turbulent diffusion decreases. This accounts for the apparent shifting of the $X / Q$ curves to the right.

Figure 8 shows concentric annuli from the initialization point with radii of $1,2,3,4,5,6,7,8,9,10,20,30$, and $40 \mathrm{miles}$ in $22.5^{\circ}$ sectors overlaid on the $x-y$ grid network. Average air concentration and deposition values after $60 \mathrm{~min}$ are given in Tables 2 and 3 corresponding to sector-averaged groundlevel values for each of the three translational velocities, respectively. Since the directional dependence of the storm has been eliminated, sector values for 180 to $360^{\circ}$ are considered to be zero. The centerline trajectory of the storm lies between sectors 4 and 5 . Appropriate assignment of the centerline trajectory of the storm to a specific direction, i.e., N, NNE, E, etc. would then give corresponding sector averages based on compass points. 


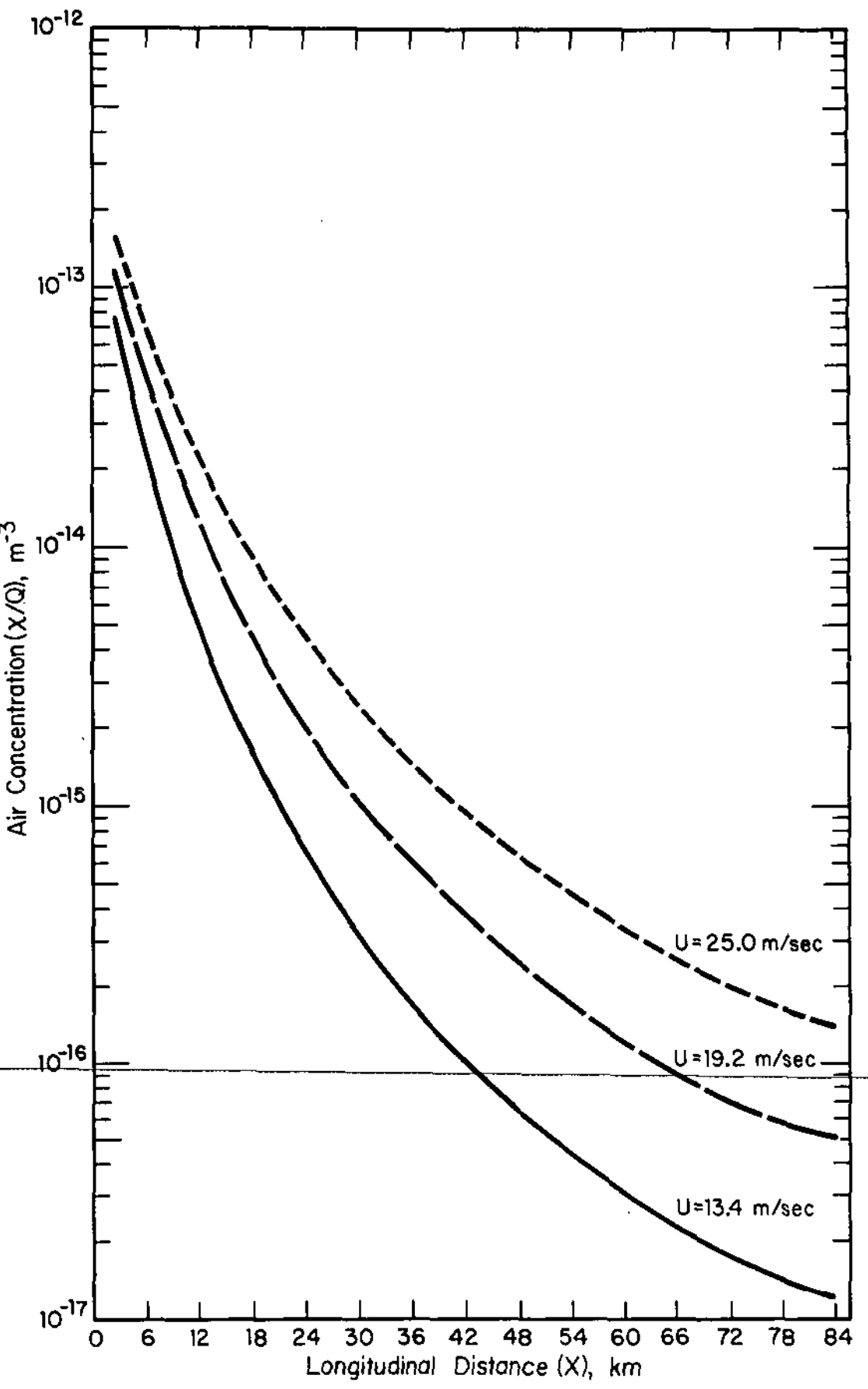

FIGURE 7. Maximum Ground Level Centerline Air Concentration $\left(\mathrm{m}^{-3}\right)$ - Modified Gaussian ModeI 


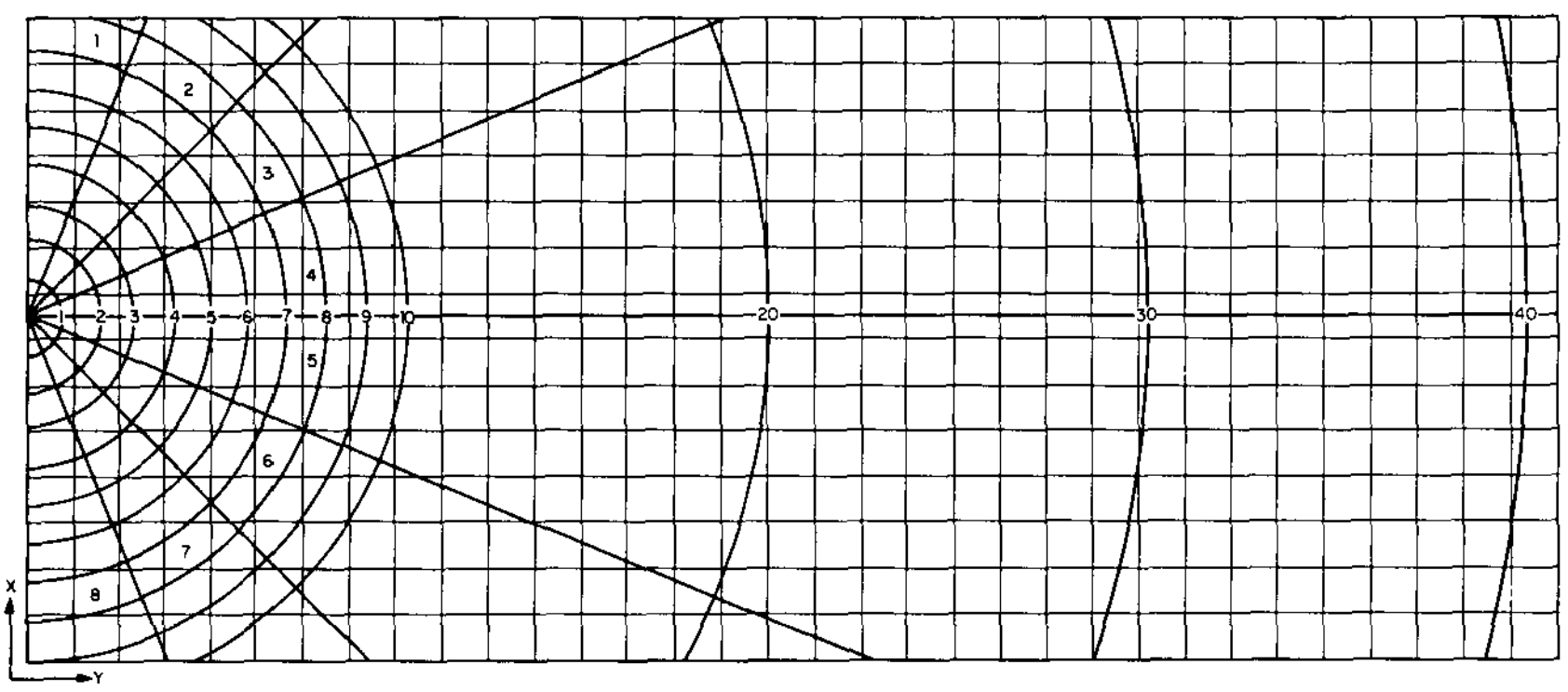

FIGURE 8. Concentric Annuli in $22.5^{\circ}$ Sectors in the $x-y$ Plane 


\section{TABLE 2}

Average Sector Air Concentration $\left(\mathrm{m}^{-3}\right)$ at Ground Leve ${ }^{*}$

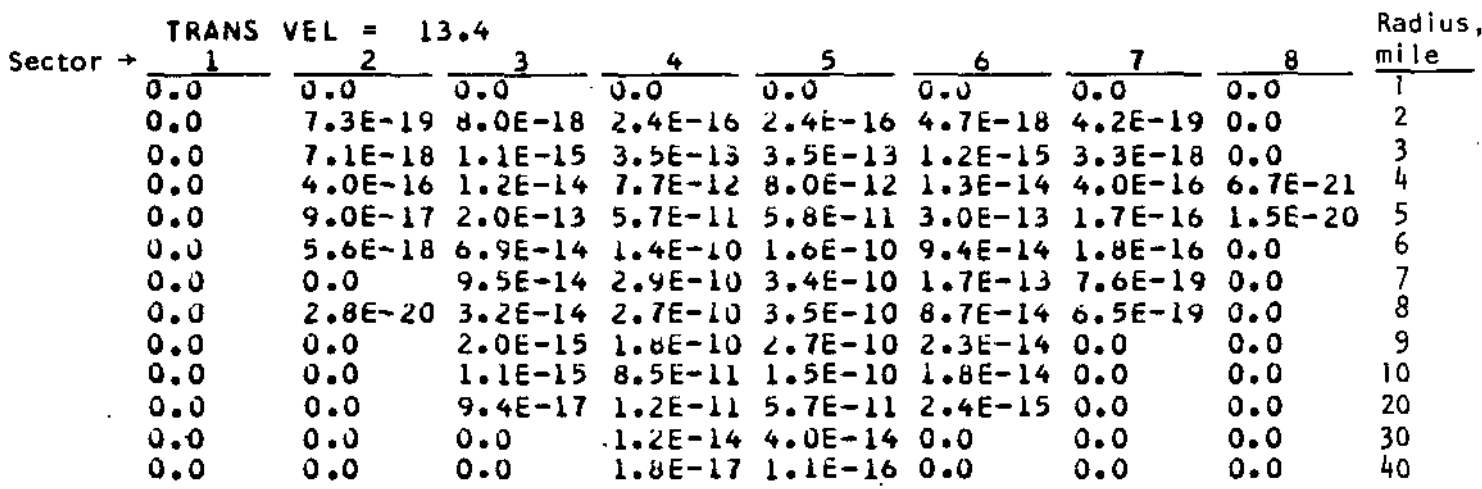

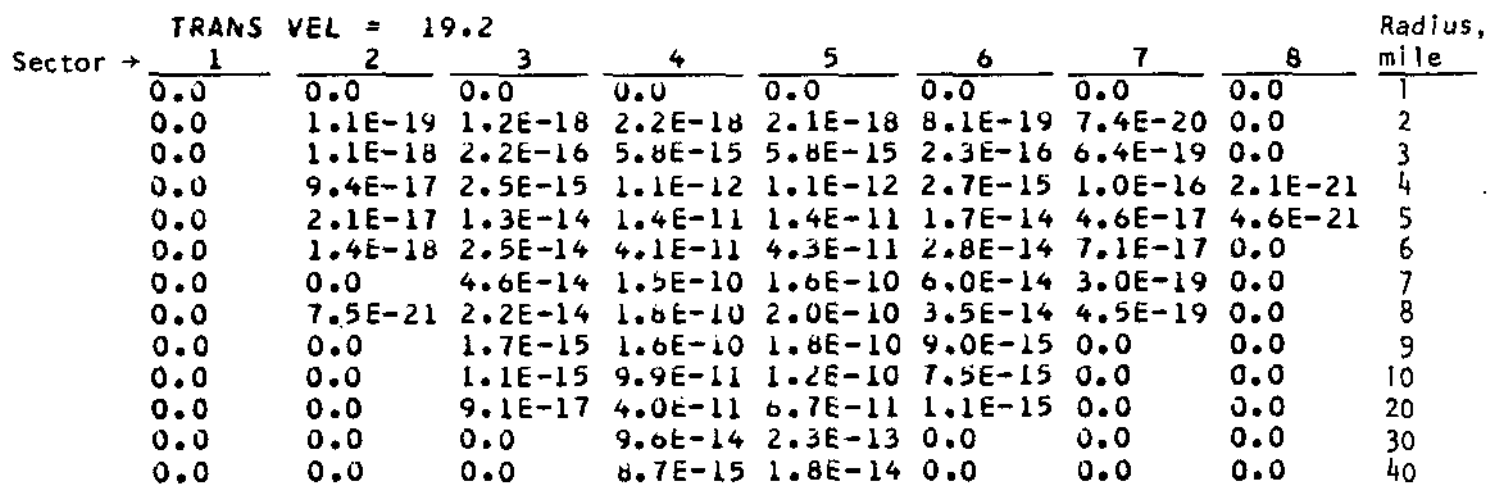

TRANS VEL $=23.0$

\begin{tabular}{|c|c|c|c|c|c|c|c|c|c|}
\hline Secto & 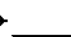 & 2 & 3 & 4 & 5 & 6 & 7 & 8 & mile \\
\hline & $\begin{array}{l}0.0 \\
0.0 \\
0.0\end{array}$ & $\begin{array}{l}0.0 \\
2.0 E-20 \\
1 . y E-19\end{array}$ & $\begin{array}{l}0.0 \\
2.2 E-19 \\
3.8 E-17\end{array}$ & $\begin{array}{l}0.0 \\
4.0 E-19 \\
9.3 E-16\end{array}$ & $\begin{array}{l}0.0 \\
4.6 E-19 \\
9.6 E-16\end{array}$ & $\begin{array}{l}0.0 \\
2.0 E-19 \\
0.6 E-17\end{array}$ & $\begin{array}{l}0.0 \\
1.8 E-20 \\
1.7 E-19\end{array}$ & $\begin{array}{l}0.0 \\
0.0 \\
0.0\end{array}$ & $\begin{array}{l}7 \\
2 \\
3\end{array}$ \\
\hline & $\begin{array}{l}0.0 \\
0.0 \\
0.0 \\
0.0 \\
0.0 \\
0.0 \\
0.0 \\
0.0 \\
0.0 \\
0.0\end{array}$ & $\begin{array}{l}2.4 E-17 \\
5.5 E-18 \\
5.1 E-19 \\
0.0 \\
3.0 E-21 \\
0.0 \\
0.0 \\
0.0 \\
0.0 \\
0.0\end{array}$ & $\begin{array}{l}6.7 E-16 \\
4.7 E-15 \\
1.1 E-14 \\
2.5 E-14 \\
2.3 E-14 \\
1.2 E-15 \\
8.7 E-16 \\
8.9 E-17 \\
0.0 \\
0.0\end{array}$ & $\begin{array}{l}2.0 E-13 \\
3.8 E-12 \\
1.2 E-11 \\
7.7 E-11 \\
1.2 E-10 \\
1.2 E-10 \\
8.2 E-11 \\
4.9 E-11 \\
2.6 E-13 \\
3.4 E-14\end{array}$ & $\begin{array}{l}2.0 E-13 \\
3.0 E-12 \\
1.2 E-11 \\
7.7 E-11 \\
1.2 E-10 \\
1.2 E-10 \\
6.5 E-11 \\
6.2 E-11 \\
4.8 E-13 \\
6.5 E-14\end{array}$ & $\begin{array}{l}7.7 E-16 \\
5.9 E-15 \\
1.4 E-14 \\
3.0 E-14 \\
1.0 E-14 \\
5.1 E-15 \\
4.2 E-12 \\
7.1 E-16 \\
0.0 \\
0.0\end{array}$ & $\begin{array}{l}3.1 E-17 \\
1.5 E-17 \\
3.1 E-17 \\
1.3 E-19 \\
3.2 E-19 \\
0.0 \\
0.0 \\
0.0 \\
0.0 \\
0.0\end{array}$ & $\begin{array}{l}8.5 E-22 \\
1.9 E-21 \\
0.0 \\
0.0 \\
0.0 \\
0.0 \\
0.0 \\
0.0 \\
0.0 \\
0.0\end{array}$ & $\begin{array}{r}4 \\
5 \\
6 \\
7 \\
8 \\
9 \\
10 \\
20 \\
30 \\
40\end{array}$ \\
\hline
\end{tabular}

* Values followed by the letter E (for exponent), minus symbol, and two digits indicate the powers of 10 by which the number must be multiplied to obtain the correct value; for example, $7.3 \mathrm{E}-19$ is $7.3 \times 10^{-19}$. 
TABLE 3

Average Sector Deposition $\left(m^{-2}\right)$ at Ground Level*

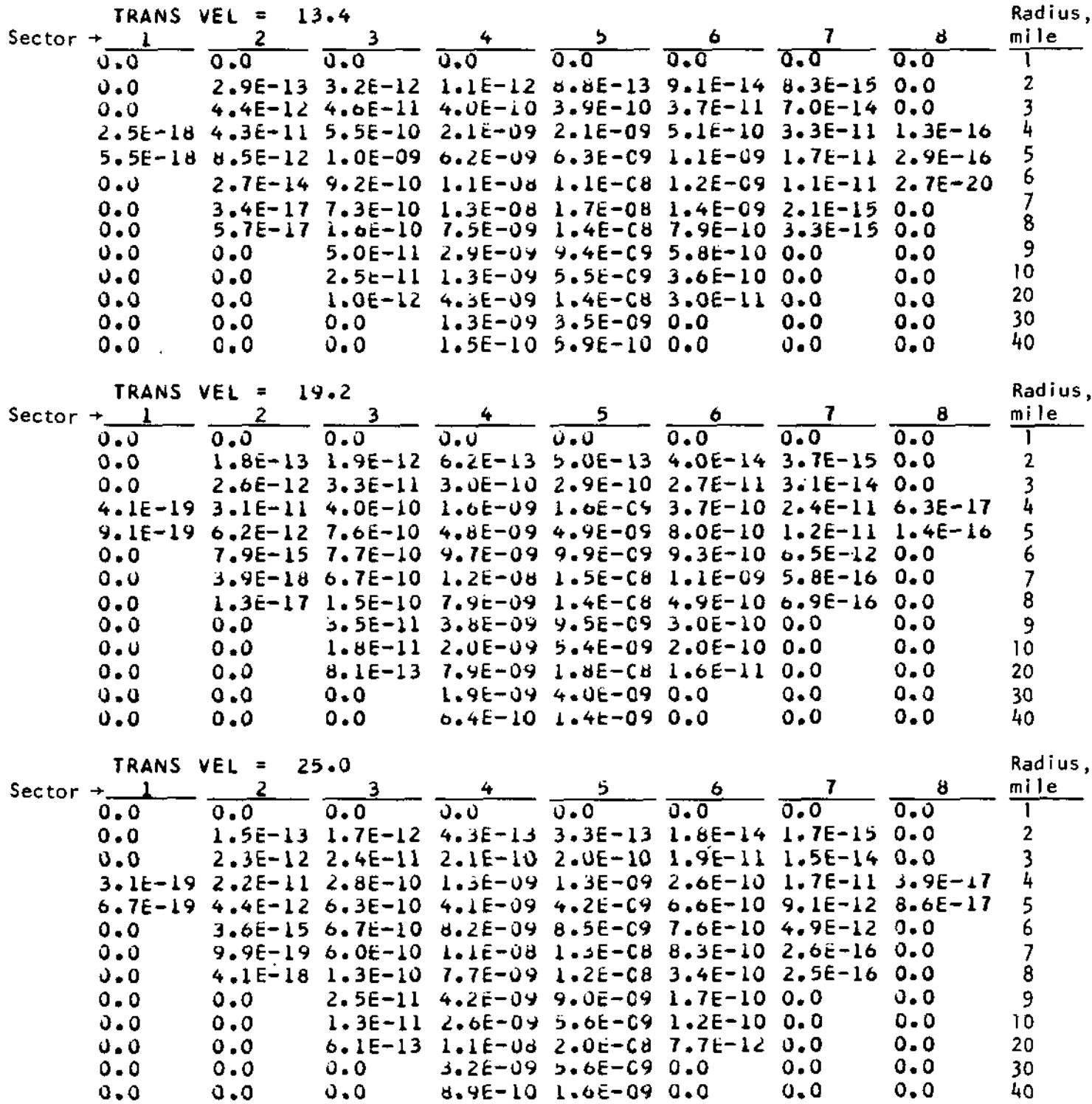

* Values followed by the letter $E$ (for exponent), minus symbol, and two digits indicate the powers of 10 by which the number must be multiplied to obtain the correct value; for example, $7.3 \mathrm{E}-19$ is $7.3 \times 10^{-19}$. 


\section{CONCLUSIONS}

A three-dimensional numerical model is used to calculate the dispersion of small particulates in a tornadic storm. The model is designed to allow various meteorological parameters to bc updated as more precise information becomes available. The three-dimensional transient equation of concentration transport is solved by a quasi-Lagrangian method of second moments in an Eulerian mesh centered over the assumed trajectory of the storm.

The horizontal wind field varies with height over the onehour period after the Babcock and Wilcox Plant is breached. The updrafts and downdrafts associated with the tornadic storm are calculated from initial empirical estimates and then advected with the storm. The horizontal rotational wind field within the storm cell is also advected with the vertical velocity field. As the storm cell spreads horizontally, the wind field within the storm cell spreads accordingly.

Because of the lack of precise information regarding turbulence within severe storms, the turbulence diffusion coefficients are obtained from empirical estimates. These estimates are based on sparse data measured within storms and theoretical equations appearing in the literature.

Scavenging is calculated as a sink term to the governing equation. Washout scavenging below the cloud base acts on large particles; rainout scavenging acts on small particles within the cloud. However, limited knowledge of scavenging in severe storms necessitates the use of a simple general expression based on rainfall rates, droplet size, and $100 \%$ collision efficiency. The effect of topography downwind of the Babcock and Wilcox Plant is introduced through specification of roughness heights used in determining turbulent diffusion below the cloud. The effect of topography on advection is not considered.

The pollutant is assumed to be dispersed throughout the thunderstorm cell. A skewed log-normal distribution is used to initialize the concentration field. Approximately $35 \%$ of the material is disbursed within the upper regions of the cloud, $15 \%$ within the middle section of the storm, and $50 \%$ within the lower layers and cloud base of the storm. Once the concentration field is established, scavenging and downdraft velocities begin to bring the concentration to the ground. 
The updraft and downdraft vertical velocity distributions and wet deposition account for most of the material being deposited at the surface one hour after initial uptake of the material. Scavenging accounts for approximately $50 \%$ of the particle removal from the cloud within $15 \mathrm{~min}$. A constant rainfall rate of $20 \mathrm{~mm} / \mathrm{hr}$ is used throughout the calculation. The deposition of concentration at the surface consists primarily of plutonium particles suspended within waterdrops. As additional information on rainfall rates and velocities in tornadic storms becomes available, deposition will likely become highly nonuniform.

Ground-1evel air concentration begins to reach the surface within $5 \mathrm{~min}$. Results show values of ground-level concentrations to begin occurring within 20 to $45 \mathrm{~km}$ from the Babcock and Wilcox Plant. Peak centerline concentrations occur within $15 \mathrm{~km}$ of the point of initial dispersion within the cloud. The concentration decreases significantly with distance after peak ground-1eve1 values are reached. The lateral spread of ground-level concentration is principally governed by the size of the thunderstorm cell directly overhead. Downdrafts and scavenging have more influence on bringing the concentration directly from the storm cell to the surface than turbulent diffusion. Concentration reaching the anvil portion of the cloud is advected at a faster velocity than concentration in the lower levels of the storm. Approximately $5 \%$ of the concentration is advected out of the anvil into the stratosphere.

Results obtained with a modified Gaussian puff model were considered to be low and showed the inflexibility of the analytical solution to account for the transient nature of the vertical wind field. Ground-level $X / Q$ values were several orders of magnitude less in value than $X / Q$ values obtained from the numerical method within $20 \mathrm{~km}$ of the point of initial dispersion within the tornadic storm. 


\section{REFERENCES}

1. T. T. Fujita. Review of Severe Weather Meteorology at Babcock and Wilcox Company, Leechburg, Pennsylvania.

A report prepared under ANL Contract No. 31-109-38-3731, University of Chicago, Chicago, IL (January 31, 1977) 24 pp.

2. K. C. Mehta, J. R. McDonald, and D. A. Smith. Response of Structures to Extreme Wind Hazard at the Babcock and Wilcox Plant, Leechburg, Pennsyzvania, Vol. I. Institute for Disaster Research, Texas Tech University, Lubbock, TX (1977) $30 \mathrm{pp}$.

3. J. Mishima, L. C. Schwendiman, and J. A. Ayer. Airborme Release of Plutonium from $B$ \& $W$ Plant as a Result of Severe Wind Hazard. Battelle Pacific Northwest Laboratories, Richland, WA (report in progress).

4. T. T. Fujita. Tomado Structure for Engineering Application with Design Basis Tornado Model (DBT-77). A report prepared under ANL Contract No. 31-109-38-3731, University of Chicago, Chicago, IL (August 1977) $111 \mathrm{pp}$.

5. D. W. Pepper. Dispersion of Smazl Particles in a Tomado. USERDA Report DP-1387, E. I. du Pont de Nemours and Company, Savannah River Laboratory, Aiken, SC (1975) 23 pp.

6. D. W. Pepper and C. D. Kern. "Modeling the Dispersion of Atmospheric Pollution Using Cubic Splines and Chapeau Functions." Advances in Computer Methods for Partial Differential Equations - II. IMACS (AICA), Department-ofComputer Science, Rutgers University, R. Vichnevetsky, Editor, New Brunswick, N.T (1977) pp 269-276.

7. B. A. Egan, and J. R. Mahoney. "Numerical Modeling of Advection and Diffusion of Urban Area Source Pollutants," J. Appl. Meterol. 11, 312-322 (1972).

8. D. W. Pepper. Calculation of Downwind Dispersion of Particulates in a Tomadic Storm. USDOE Report DPE. I. du Pont de Nemours and Company, Savannah River Laboratory, Aiken, SC (to be issued).

9. D. W. Pepper and P. E. Long. "A Comparison of Results Using Second Order Moments with and without Width Correction to Solve the Advection Equation." J. Applied Meterol. 17, (1978). 
10. F. Pasquill, Winnersh, Berkshire, U.K.

Personal Communication (1976).

11. T. T. Fujita, University of Chicago, Chicago, IL. Personal Communication (1977).

12. J. R. Eagleman. and W. C. Lin. "Severe Thunderstorm Internal Structure from Dual-Doppler Radar Measurements."

J. App Z. Meterol. 16, 1036-1048 (1977).

13. W. G. Slinn. "In-Cloud Scavenging of Aerosol Particles," Annual Report for 1974. Part III. Atmospheric Sciences. USAEC Report BNWL-1950 (Pt. 3), Battelle Northwest Laboratories, Richland, WA (February 1975) pp 114-118.

14. T. T. Fujita, M. R. Hjelmfelt, and S. A. Changnon. "Meso-analysis of Record Chicago Rainstorms Using Radar, Satellite, and Rain Gauge Data," Tenth Conference on Severe Local Storms, October 18-21, Omaha, Nebraska, pp 65-72 (1977).

15. W. E. Davis. "A Model for In-Cloud Scavenging of Cosmogenic Radionuclides." J. Geophys. Res. 77, No. 12, 2159-2165 (1972) .

16. C. E. Hane. "Precipitation Scavenging in a Squall Line: Numerical Experimentation." Annual Report for 1974. Part III. Atmospheric Sciences. USAEC Report BNWL-1950 (Pt. 3), Battelle Northwest Laboratories, Richland, WA (February 1975) pp 143-149. 